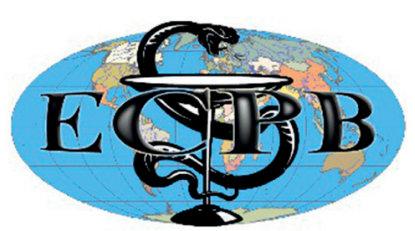

“ЕКСПЕРИМЕНТАЛЬНА ТА КЛІНІЧНА ФІЗІОЛОГІЯ І БІОХІМІЯ” "EXPERIMENTAL AND CLINICAL PHYSIOLOGY AND BIOCHEMISTRY" Науково-практичний журнал/Scientific-practical journal

UDC 612.281:577.15:616155.32

\title{
Characteristics of antioxidant and NO-synthase systems of blood lymphocytes under the action of decamethoxine
}

\author{
I.V. KOVALENKO, O.K. ONUFROVYCH, R.V. FAFULA, O.V. MELNYK, Z.D. VOROBETS
}

Danylo Halytskyi Lviv National Medical University. Lviv, Ukraine

Email: kaf_medicalbiology@meduniv.lviv.ua

Introduction. Antiseptics are widely used in the system of antimicrobial measures for the prophylaxis and treatment of infectious diseases [1-4]. Antiseptic drugs have mostly the microbicidal effect on the skin surface, mucous membranes and surfaces of a wound and body cavities [1-4]. They are dissolved in water and lipids. One of the most widespread antiseptics is the drug 'Decamethoxine'. Other drugs such as horosten, decasan, auridexan, septephril were created on its basis [2,3]. Decamethoxine is a chemical compound [1, 10-decamethylene bis (N, N - dimethylmethoxycarbonylmethyl) ammonium dichloride] that has a wide range of the antimicrobial action on Gram-positive (staphylococcus, streptococcus, pneumococcus), Gram-negative (gonococcus, meningococcus) cocci, diphtheria corynebacteria, enterobacteria, pseudomonads, protozoa, dermatophytes, yeasts-like fungi of the genus Candida, chlamydia and viruses. When applied, the formation of variants of microorganisms resistant to decamethoxine occurs very slowly.

Since decamethoxine is a surfactant, it changes the permeability of membranes of microbial cells which leads to the degradation and destruction of microorganisms and this determines its bactericidal action [5]. However, the antiseptic action of this substance is based not only on the bactericidal, but also on bacteriostatic activity.

Pathological processes that occur in the cells of the body when inflammatory processes and pathological conditions are caused primarily by the violation of regulatory systems, the activation of lipid peroxidation processes and the violation of the antioxidant protective system [6-10].

Under the influence of extreme factors of different origin on organisms, the formation of reactive oxygen species (ROS) in living organisms increases. Under normal physiological conditions, ROS is not accumulated in cells. Any stress response of the organism is usually accompanied by a short-term increase in the number of ROS. ROS activates the expression of redox-sensitive genes in cells, many of which are required to protect cells from the toxic effects of oxidative stress, particularly glutathione peroxidase, catalase, superoxide dismutase, glutathione reductase, $\mathrm{Y}$-glutamylcysteine synthetase.

A number of antioxidant systems plays a major role in the neutralization of secondary peroxidation products and other oxidizing materials, namely, glutathione antiperoxide system as the most powerful one $[8,10]$. Due to the catalytic activity of glutathione peroxidase (GP) in cells, the reduction of $\mathrm{H}_{2} \mathrm{O}_{2}$ and hydroperoxides of organic molecules to corresponding hydroxy compounds occurs. This process is performed by using reduced glutathione.

(C) Kovalenko I.V., Onufrovych O.K., Fafula R.V. et al., 2020 
Glutathione reductase (GR) is a NADPH-dependent enzyme that provides the reaction of reduction of the oxidized form of glutathione and recycling of GSH, respectively. This protective system also includes glutathione transferase (GT), the enzyme that catalyzes the conjugation of reduced glutathione with electrophilic compounds, performing a protective function [8].

Since decamethoxine has hydrophilic and lipophilic properties, it can penetrate into cells, blood through surfaces of a wound, mucous membranes, skin, etc., and can be transmitted by blood to different organs and tissues, thus causing a variety of biochemical effects, regarding the regulatory of NO-synthase system of cells. In this respect, the biological action of decamethoxine has not been investigated substantially.

Since the intracellular lymphocyte metabolism is based on the physiologicallyand biochemically-fixed ability of these cells to respond quickly to any changes in homeostasis in the body, they can be a convenient and adequate model for the study of pathophysiological and regulatory disorders in the organism.

The aim of the study is to investigate the pro- / antioxidant and NO-synthase systems of blood lymphocytes under the action of decamethoxine.

Materials and methods. The studies have been performed on blood lymphocytes of healthy women. The total number of practically (clinically) healthy women, representatives of the age group (mean age 53.8 \pm 5.4 years) was 44 . This group was formed by volunteers from the staff of Danylo Halytsky Lviv National Medical University and employees of Lviv State Regional Oncology Treatment and Diagnostic Center.

Peripheral blood lymphocytes were isolated by means of Boyum method in a density gradient of ficol triumbrast $\left(\rho=1.08 \mathrm{~g} / \mathrm{cm}^{3}\right)$.

The integrity and viability of blood lymphocytes in all experiments were at least $95 \%$.

Saponin was added to the suspension for permeabilization of blood lymphocytes membranes and for the disclosure of latent enzymatic activities. This technique is based on works performed on lymphocytes previously [11]. Blood lymphocytes were incubated during 10 min with moderate shaking in a solution, containing $0.2 \%$ saponin (optimal concentration).

The determination of glutathione peroxidase activity was carried out on the basis of the color reaction development with 5-5'-dithiobis (2-nitrobenzoic acid) (DTNB) with the formation of a colored product of thionitrophenol anion which amount is directly proportional to the number of $\mathrm{SH}$-groups that have reacted with DTNB. The activity of the enzyme was expressed in nmol GSH / min per $1 \mathrm{mg}$ of protein. GP activity was measured by the rate of GSH oxidation in presence of tert-butyl hydroperoxide solution (TBHP, t-BuOOH). GR activity was expressed in nmol of NADPH / min per $1 \mathrm{mg}$ of protein.

The activity of GT was measured by the rate of the enzymatic formation of glutathione-S in the reaction of the glutathione reduction with 1-chloro-2,4 dinitrobenzene. GT activity was expressed in nmol GSH / min per $1 \mathrm{mg}$ of protein.

The amount of reduced glutathione was expressed in nmol GSH / $\mathrm{mg}$ of protein.

The principle of the MDA method of determination was that at high temperature in acidic medium, it reacts with 2-thiobarbituric acid, creating the trimethylene colored complex with a maximum absorption at $\lambda=532 \mathrm{~nm}$.

The arginase activity of peripheral blood lymphocytes was measured by the urea production, which content was measured using a diagnostic kit in accordance with the instructions of the manufacturer (Simko, Ukraine). Arginase activity was expressed in nmol of urea/mg of protein.

NO synthase activity was measured by its ability to oxidize $\mathrm{NADPH}\left(\mathrm{H}^{+}\right)$ at presence of L-arginine as a substrate $[12,13]$.The activity of cNO-synthase was calculated as the difference between the total activity of $\mathrm{NO}$-synthase and the activity of $\mathrm{Ca}^{2+}$-independent isoform of $\mathrm{NO}$-synthase. 
The protein content of the lymphocyte mixture was determined by a modified Lowry method.

Results and discussion. The intensification of the lipid peroxidation leads to the accumulation of toxic products, accompanied by a body resistance decrease. Simultaneously, the buffering capacity of the antioxidant system, being quite large, is provided by various components. An important place among AOS of the cell is occupied by the glutathione system, whose components are involved in both enzymatic (glutathione peroxidase, glutathione reductase, glutathione transferase) and non-enzymatic (glutathione) reactions of AOS $[8,10]$. Although, the glutathione system has been the subject of many researches, there is no consensus in the literature on its role in the development of pathological conditions, inflammatory processes, the action of antiseptics and antibiotics on the body. In this regard, the analysis of the functional state of the glutathione system and lipid peroxidation will allow us to clarify the action mechanism of the antiseptic decamethoxine in details.

We have conducted a comparative study of the LPO system and glutathione in peripheral blood lymphocytes under the action of decamethoxine.

A slight inhibition of LPO processes under the action of different concentrations of decamethoxine is shown, being evaluated by determining the concentration of malondialdehyde which is a secondary product of lipid peroxidation (Fig. 1). Thus, the concentration of MDA in blood lymphocytes is $(62,3 \pm 4,6)$ $\mathrm{nmol} / \mathrm{mg}$ of protein in the control group, while under the influence of different concentrations of decamethoxine $\left(10^{-5}-10^{-2} \mathrm{M}\right)$, this value decreases to $(55,1 \pm 4,3)$ $\mu \mathrm{mol} / \mathrm{mg}$ of protein $(\mathrm{p}>0,001)$.

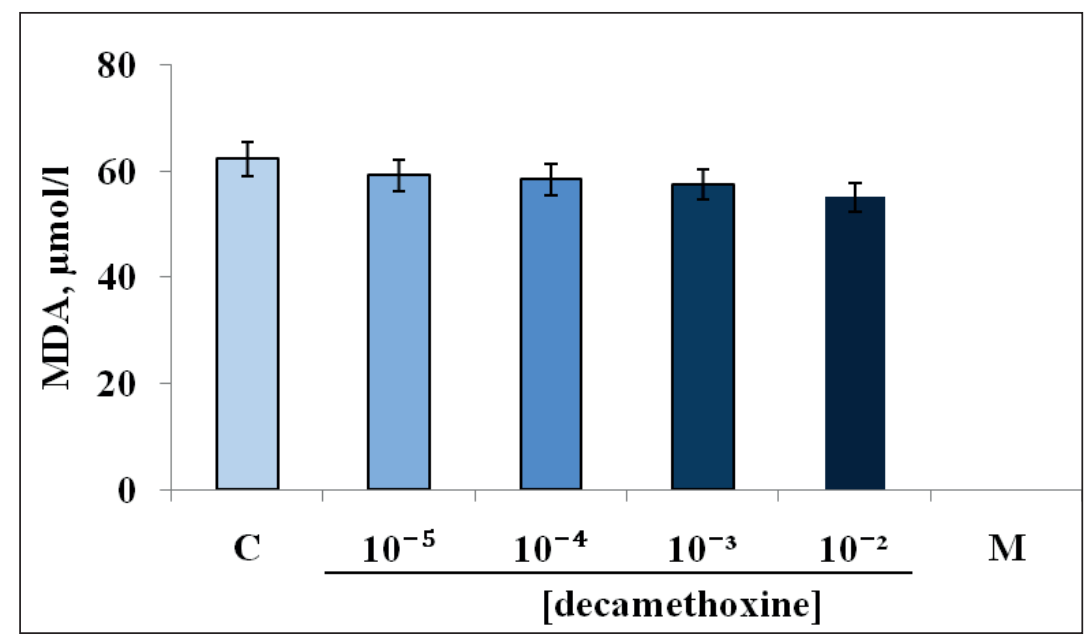

Fig. 1. The concentration of malondialdehyde in the blood lymphocytes of healthy women (the control group) and under the action of different concentrations of decamethoxine.

Note: changes are unlikely in values of the control group, $p>0,001$.

Thus, significant changes in blood cells in the process of lipid peroxidation, being exposed to decamethoxine, were not found, although, there was a tendency to decrease. Fluoroquinolones had the opposite effect on the processes of LPO unlike decamethoxine. All of the previously studied fluoroquinolones have dose-dependent activation of LPO processes.

Simultaneously, with a slight decrease in LPO processes, the appropriate changes in the activity of glutathione system enzymes were revealed (Figure 2). Thus, it was shown that lymphocyte glutathione peroxidase activity is $(154,2 \pm 13,4) \mathrm{nmol} \mathrm{GSH} / \mathrm{min} \cdot \mathrm{mg}$ of protein in the control group. Under the action of decamethoxine, this activity increases dose-dependently and reaches 
$181,2 \pm 13,3) \mathrm{nmol} \mathrm{GSH} / \mathrm{min} \cdot \mathrm{mg}$ of protein $(\mathrm{p}<0,05)$. However, the concentration of reduced glutathione under the action of decamethoxine remained virtually unchanged and ranged from 17,2 to $18,4 \mathrm{nmol} \mathrm{GSH} / \mathrm{mg}$ of protein. As we have previously demonstrated, fluoroquinolones stimulate glutathione peroxidase activity dose-dependently too [14].

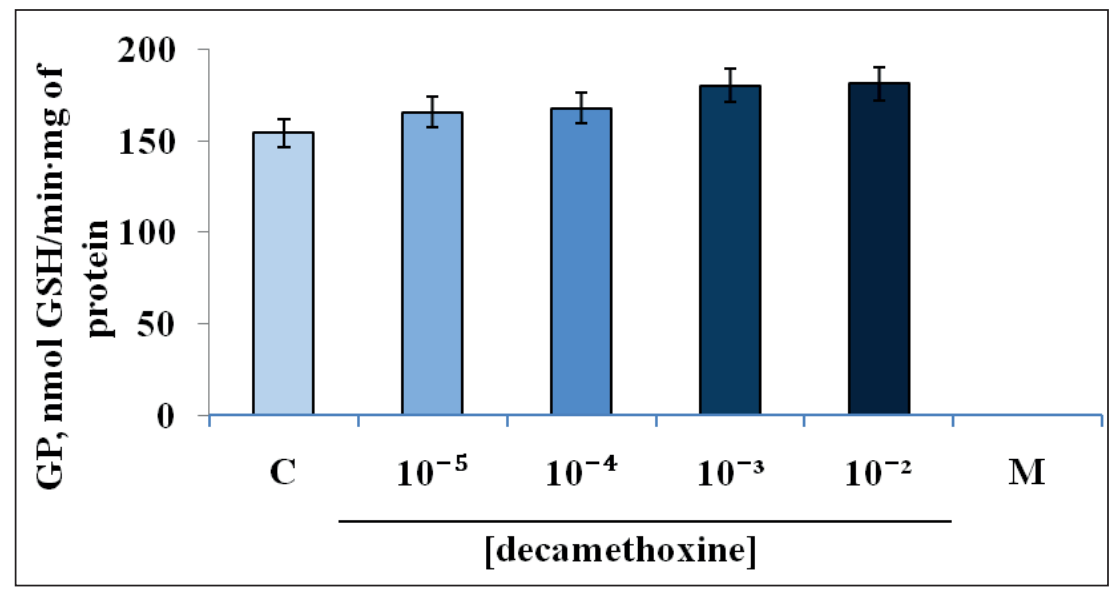

Fig. 2. Glutathione peroxidase activity of blood lymphocytes under the action of different concentrations of decametoxine.

In relation to the activity of glutathione reductase of the control group, it was $(51,7 \pm 4,2) \mathrm{nmol} \mathrm{NADPH} / \mathrm{min} \cdot \mathrm{mg}$ of protein (Fig. 3). When exposed to decamethoxin at concentrations of $10^{-5}-10^{-2} \mathrm{M}$, this dose-dependent activity increased to $(62,3 \pm 5,4) \mathrm{nmol} \mathrm{NADPH} / \mathrm{min} \cdot \mathrm{mg}$ of protein, that is in 1,2 times relatively to the control group $(\mathrm{p}<0,05)$.

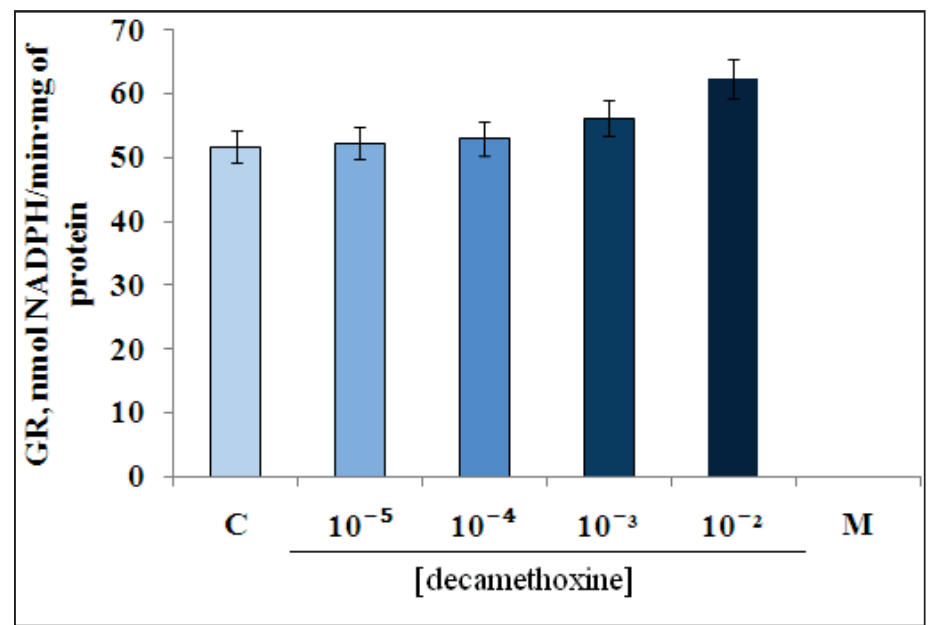

Fig. 3. The activity of glutathione reductase of blood lymphocytes under the action of different concentrations of decamethoxine.

Glutathione S-transferase activity was $(112,2 \pm 9,2) \mathrm{nmol} \mathrm{GSH} / \mathrm{min} \cdot \mathrm{mg}$ of protein in the control group (Fig. 4). Being added to the incubation medium of decamethoxine at concentrations of $10^{-5}-10^{-2} \mathrm{M}$, this enzyme was activated dose-dependently, its activity increased to $(156,6 \pm 12,4) \mathrm{nmol} \mathrm{GSH} / \mathrm{min} \cdot \mathrm{mg}$ of protein, that is in 1,4 times $(p<0,05)$. Similar to the effect of decamethoxine, fluoroquinolones (ciprofloxacines, levofloxacine, moxifloxacine) caused the activation of this enzyme too [14]. 


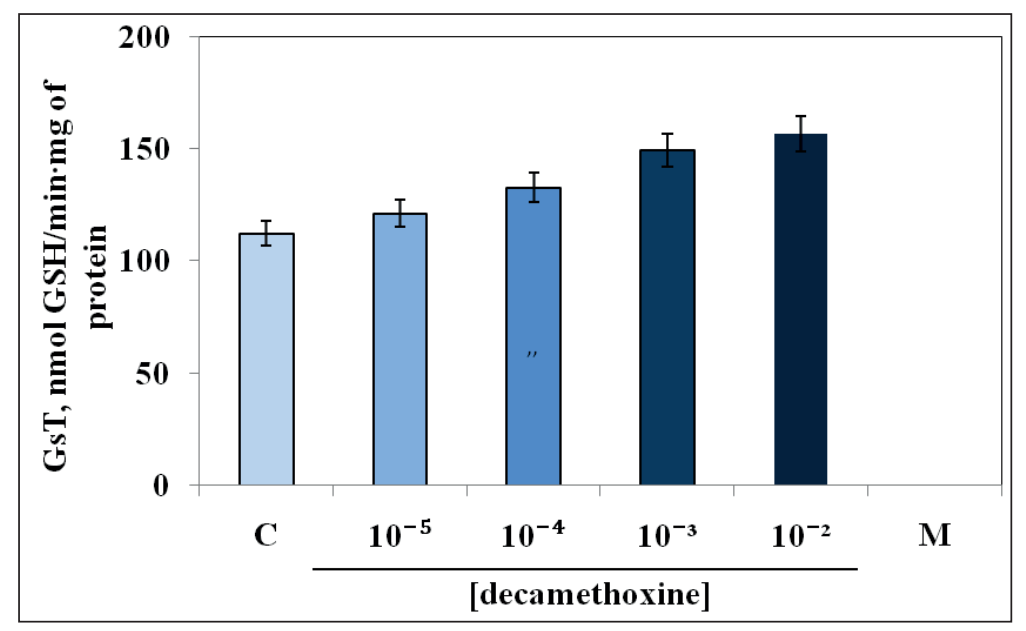

Fig. 4. Glutathione S-transferase activity of blood lymphocytes under the action of different concentrations of decamethoxine.

The effect of decamethoxine on the activity of the arginase-NO-synthase system of blood lymphocytes was also demonstrated. Dose-dependent decamethoxine activated the arginase activity up to $(175,1 \pm 8,8) \mathrm{nmol}$ urea/min $\cdot \mathrm{mg}$ of protein at $10^{-2} \mathrm{M}$ concentration, that is in 1,4 times relatively to the control group $(\mathrm{p}<0,05)$ (Fig. 5). All fluoroquinolones including dose dependent ones that activated this enzyme as well were studied by us [15].

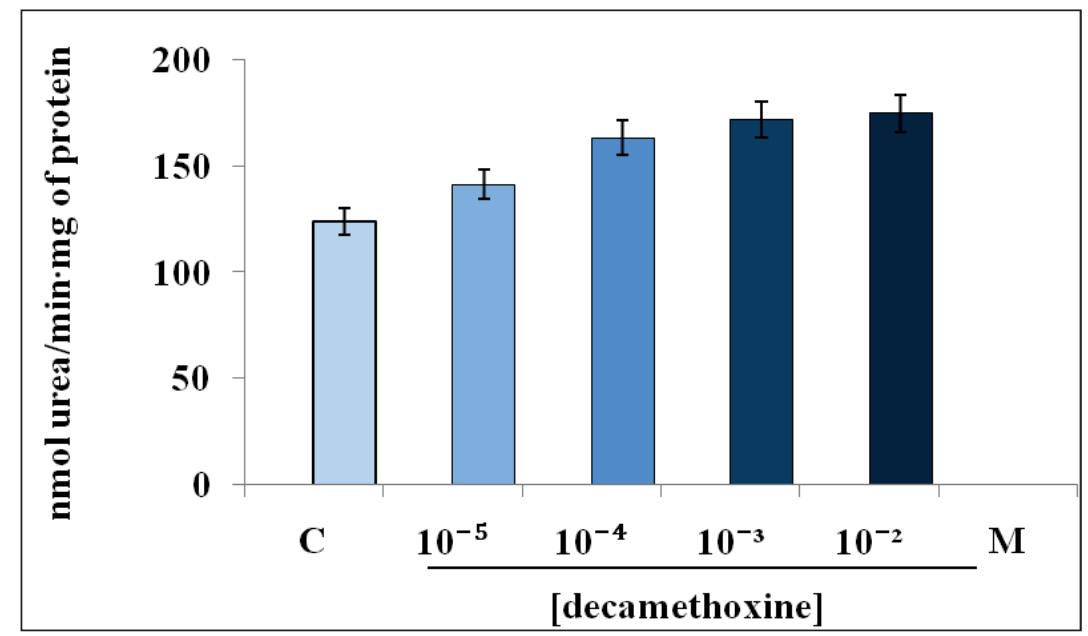

Fig. 5. Arginase activity of blood lymphocytes under the action of different concentrations of decamethoxine.

It has been established that the cNOS activity of blood lymphocytes in the control group was $71,4 \pm 6,9$ and the activity of the inducible isoform was $1,58 \pm 0,18 \mathrm{nmol} \mathrm{NADPH}\left(\mathrm{H}^{+}\right) / \mathrm{min} \cdot \mathrm{mg}$ of protein (Fig. 6). With the action of decamethoxine at a concentration of $10^{-5} \mathrm{M}$, the activity of cNOS decreased in 1,25 times $(p<0,05)$, while the activity of iNOS increased in 10,8 times $(p<0,001)$. In our previous studies, we showed that antibiotics fluoroquinolones inhibited the activity of cNOS blood lymphocytes more effectively [15]. 


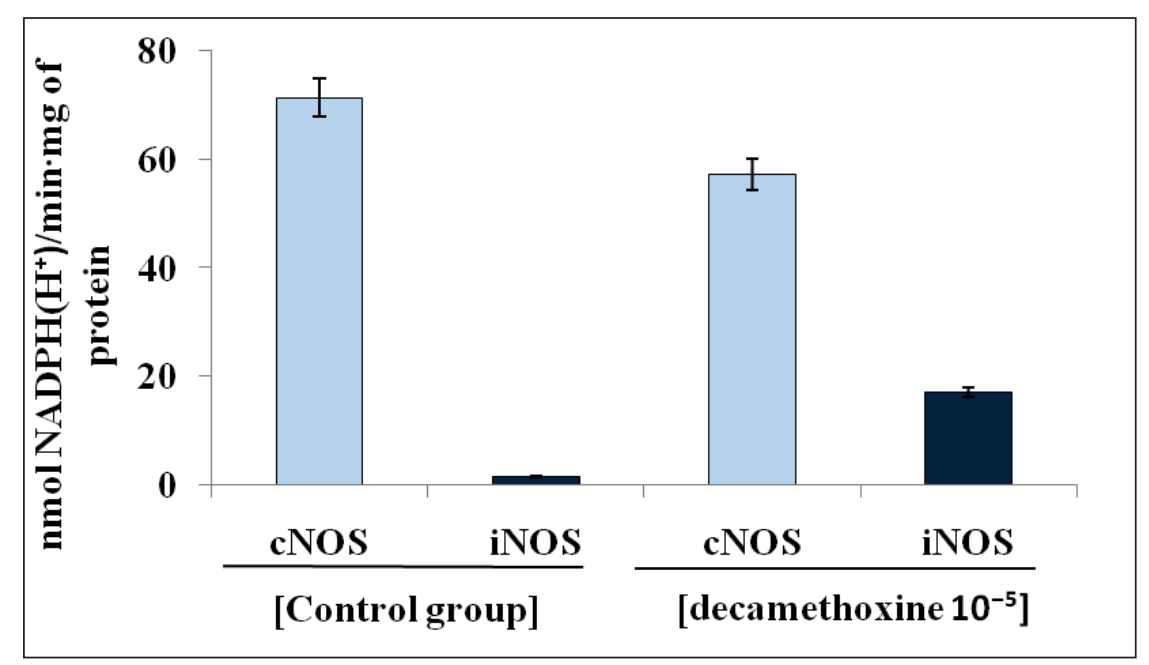

Fig. 6. The activity of constitutive and inducible isoforms of NO-synthase of blood lymphocyte under the action of different concentrations of decamethoxine.

Thus, it has been shown that in addition to its effect on the antioxidant system, decamethoxine has also an effect on the arginase-NO-synthase system.

Conclusion. It has been found that decamethoxine significantly influences the regulatory mechanisms of the cell, blood lymphocytes, in particular. It activates the enzymes of the glutathione antioxidant system, stimulates the activity of arginase and inhibits the activity of the constitutive isoform of NO synthase with the simultaneous activation of the inducible isoform of NO synthase.

The study was performed within the framework of the complex scientific work of Lviv Danylo Halytsky National Medical University «The investigation of role of systemic and paracrine regulatory mechanisms in providing homeostatation of functional and metabolic parameters of the organism under the conditions of adaptation to the action of extreme factors of different nature» (the state registration number 0116U004510).

\section{REFERENCES}

1. Gonchar OO, Nazarchuk OA, Paliy DV, Kovalenko IV, Yatsula OV, Burkot VM. The research of the activity of decamothoxin and its medicinal forms on adhession of bacteria. Journal World of Medicine and Biology. 2015. 4(54):109-112 (in Ukrainian).

2. Nazarchuk OA, Chereshniuk IL, Nazarchuk GG, Palii DV. Current antiseptics: a study on their antimicrobial activity and toxic effects on the corneal epithelium. Journal Ophthalmology. 2019;3:26-31.

3. Nazarchuk OA, Paliy VG, Gonchar OO, Oliynyk DP, Nazarchuk GG, Paliy IG. The microbiological analysis of the effectiveness of modern antiseptics and antimicrobial materials. Clinical pharmacy. 2014;18(4):8-11 (in Ukrainian).

4. Paliy VG, Nazarchuk OA, Paliy DV, Iakovets KI. Substantiation of medical use of antimicrobial remedies, containing decamethoxin. Bukovinian Medical Herald. 2017;21(1):100105 (in Ukrainian).

5. Pashynskaya VA, Kosevich MV, Gomory A, Vashchenko OV, Lisetski LN. Mechanistic investigation on the interaction between bisquaternary antimicrobial agents and phospholipids by liquid secondary ion mass spectrometry and differential scanning calorimetry. Rapid Communication in Mass Spectrometry. 2002;16(18):1706-13.

6. Ayala A, Munoz MF, Arguelles S. Lipid peroxidation: production, metabolism, and signaling mechanism of malondialdehyde and 4-hydroxy-2-nonenal. Oxidative Medicine and Cellular Longevity. 2014;2014:1-31.

7. Birben E, Sahiner MU, Sackesen C, Erzurum S, Kalayci O. Oxidative stress and antioxidant defense. World Allergy Organ Journal. 2012;5(1):9-19.

8. Bolin A, Guerra B, Nascimento S, Otton R. Change in lymphocyte oxidant/antioxidant parameters after carbonyl and antioxidant exposure. Intern. Immunopharmacology. 2012;14(4):690-97. 
9. Gautam N, Das S, Mahapatra SK, Chakraborty SP, Kundu PK, Roy S. Age associated oxidative damage in lymphocytes. Oxidative Medicine and Cellular Longevity. 2010;3(4):275-82. doi: 10.4161/oxim.3.4.12860.

10. Jurcovic S, Osredkar J, Marc J. Molecular impact of glutathione peroxidases in antioxidant processes. Biochemia Medica. 2008;18(2):162-74.

11. Fafula RV, Iefremova UP, Luchkovska NE, Vorobets ZD, Kulachkovskii O.R. Methodological approach to the study of the enzymatic spectrum of lymphocytes at pathological states using a detergent of saponin (ultrastructural study). Visnyk Problem Biologii i Medecini. 2012;1(96):163-66 (in Ukrainian).

12. Peretiatko YuV, Sybirna NO. Pecularities of arginase and NO-synthase pathways of L-arginine metabolism in leucocytes of peripheral blood of rats in conditions of chronic x-ray irradiation]. Ukrainskii Biokhimicheskii Zhurnal. 2009 Mar-Apr;81(2):40-8 (in Ukrainian).

13. Ochoa A, Zea H, Hernandez C, Rodriguez PC. Arginase, prostaglandins, and myeloidderived suppressor cells in renal cell carcinoma. Clinical Cancer Research. 2007;13:721-26.

14. Kovalenko IV, Onufrovych OK, Melnyk OV, Korchynska OS, Vorobrts NM, Vorobets $Z D$. Effect of fluoroquinolones jn the activity of the glutathione system in the peripheral blood lymphocytes. Experimental and Clinical Physiology and Biochemistry. 2019;3(87):23-9.

15. Kovalenko IV, Onufrovych OR, Vorobets NM, Melnyk OV, Vorobets ZD. Arginase/NOsynthase system characteristics $n$ blood lymphocytes under effect of fluoroquinolones. Regulatory Mechanisms in Biosystems. 2019;10(2):203-8.

Стаття надійшла до редколегії 26.02.20 р.

RESEARCH ARTICLE

Characteristics of antioxidant and NO-synthase systems of blood lymphocytes under the action of decamethoxine

\author{
I.V. KOVALENKO, O.K. ONUFROVYCH, R.V. FAFULA, O.V. MELNYK, \\ Z.D. VOROBETS \\ Danylo Halytskyi Lviv National Medical University. Lviv, Ukraine
}

Email: kaf_medicalbiology@meduniv.lviv.ua

Antiseptic drugs have mostly microbicidal effect on the skin surface, mucous membranes, surfaces of a wound and body cavities. Decamethoxine is a chemical compound [1, 10-decamethylene bis (N, N - dimethylmethoxycarbonylmethyl) ammonium dichloride] that has a wide range of antimicrobial actions on Gram-positive (staphylococcus, streptococcus, pneumococcus), Gram-negative (gonococcus, meningococcus) cocci, diphtheria corynebacteria, enterobacteria, pseudomonads, protozoa, dermatophytes, yeasts-like fungi of the genus Candida, chlamydia and viruses. Pathological processes that occur in the cells of the body when inflammatory processes and pathological conditions are caused primarily by the violation of regulatory systems, the activation of lipid peroxidation processes and the violation of antioxidant protective system. Since decamethoxine has hydrophilic and lipophilic properties, it can penetrate into cells, blood through surfaces of a wound, mucous membranes, skin, etc., and be transmitted by blood to different organs and tissues, thus causing a variety of biochemical effects, particularly regarding to the regulatory NO-synthase system of cells. In this respect the biological action of decamethoxine has not been investigated substantially.

Since the intracellular lymphocyte metabolism is based on the physiologically- and biochemically-fixed ability of these cells to respond quickly to any changes in homeostasis in the body, they can be a convenient and adequate model for the study of pathophysiological and regulatory disorders in the organism.

We have conducted a comparative study of the LPO system and glutathione in peripheral blood lymphocytes under the action of decamethoxine. A slight inhibition of LPO processes under the action of different concentrations of decamethoxine is shown which was evaluated by determining the concentration of malondialdehyde, being a secondary product of lipid peroxidation. Thus, the concentration of MDA in blood lymphocytes is $(62,3 \pm 4,6) \mathrm{nmol} / \mathrm{mg}$ of protein in the control group, while under the influence of different concentrations of decamethoxine $\left(10^{-5}-\right.$ $10^{-2} \mathrm{M}$ ) this value decreases to $(55,1 \pm 4,3) \mu \mathrm{mol} / \mathrm{mg}$ of protein $(p>0,001)$. Significant changes in blood cells in the process of lipid peroxidation have been observed when they are not exposed to decamethoxine, however, there is a tendency to decrease. 
Simultaneously, with a slight decrease in the process LPO, the appropriate changes in the activity of glutathione system enzymes were revealed. Thus, it was shown that lymphocyte glutathione peroxidase activity is $(154,2 \pm 13,4) \mathrm{nmol} \mathrm{GSH} / \mathrm{min} \cdot \mathrm{mg}$ of protein in the control group. Under the action of decamethoxine, this activity increases dose-dependently and reaches $181,2 \pm 13,3) \mathrm{nmol} \mathrm{GSH} / \mathrm{min} \cdot \mathrm{mg}$ of protein $(\mathrm{p}<0,05)$. However, the concentration of reduced glutathione under the action of decamethoxine remained virtually unchanged and ranged from 17,2 to $18,4 \mathrm{nmol} \mathrm{GSH} / \mathrm{mg}$ of protein. Glutathione S-transferase activity was $(112,2 \pm 9,2) \mathrm{nmol}$ GSH/min $\cdot \mathrm{mg}$ of protein in the control group. While being added to the incubation medium of decamethoxine at concentrations of $10^{-5}-10^{-2} \mathrm{M}$, this enzyme was activated dose-dependently, its activity increased to $(156,6 \pm 12,4) \mathrm{nmol} \mathrm{GSH} / \mathrm{min} \cdot \mathrm{mg}$ of protein, that is in 1,4 times $(\mathrm{p}<0,05)$.

The effect of decamethoxine on the activity of the arginase-NO-synthase system of blood lymphocytes was also demonstrated. Decamethoxine dose-dependent activated arginase activity up to $(175,1 \pm 8,8) \mathrm{nmol}$ urea/min $\cdot \mathrm{mg}$ of protein at $10^{-2} \mathrm{M}$ concentration, that is 1,4 times relatively to the control group $(p<0,05)$. It has been established that the cNOS activity of blood lymphocytes in the control group was $71,4 \pm 6,9$ and the activity of the inducible isoform $1,58 \pm 0,18 \mathrm{nmol}$ $\operatorname{NADPH}\left(\mathrm{H}^{+}\right) / \mathrm{min} \cdot \mathrm{mg}$ of protein. With the action of decamethoxine at a concentration of $10^{-5} \mathrm{M}$, the activity of cNOS decreased in 1,25 times $(p<0,05)$ while the activity of iNOS increased in 10,8 times $(\mathrm{p}<0,001)$.

Thus, it has been found that decamethoxine significantly influences the regulatory mechanisms of the cell, blood lymphocytes in particular. It activates the enzymes of the glutathione antioxidant system, stimulates the activity of arginase and inhibits the activity of the constitutive isoform of NO synthase with the simultaneous activation of the inducible isoform of NO synthase.

Key words: decamethoxine, lymphocytes, glutathione, arginase, NO-synthase. 